\title{
Impact of Foreign Aid on Fiscal Behaviour: A Case Study of Pakistan (1980-2000)
}

\section{Salman Ahmad*}

\begin{abstract}
Economists have been trying to study the linkages between aid inflow and government activities in developing countries. With the passage of time, the analysis has become more sophisticated. The development of two-gap models [for example, Chenery and Bruno(1962); and Chenery and Adelman(1966), among others] was an important contribution to the literature. More recently, two-gap models have been extended into threegap models. Iqbal (1995) added a fiscal constraint to the traditional saving and foreign exchange gap. In such cases, the fiscal constraint is intended to reflect potential limitations to finance public investment that may be required to support a given level of output.
\end{abstract}

Another development is the analysis of effectiveness of foreign aid on the fiscal behaviour of governments in underdeveloped countries. Empirical studies by Khilji and Zampelli(1991), Khan and Hoshino(1992), among others are important contributions to this topic. All these studies gave conflicting conclusions about the effectiveness of assistance in terms of fiscal behaviour. Generally, these studies prove that aid reduces the taxation effort and is substituted between public investment and public consumption.

The purpose of this paper is to examine the impact of foreign aid on the behaviour of recipient countries like Pakistan. The response is measured in terms of their public investment and consumption as well as taxation. Both official and unofficial grants and loans from bilateral and multilateral sources are included in aid. It is postulated that the government's expenditure and revenue efforts are affected by foreign aid through a reallocation within the categories of public expenditures and revenue raising. Various previous research studies have found evidence for considerable dissipations of aid in the form of government consumption (Please.1967:Papanek, 1973; Wejsskopf, 1972a, 1972b; and Heller, 1974). Many researchers concentrate at the macro level on the relationship between foreign aid, domestic savings and economic growth (see, for example, Griffin and Enos, 1970).Recent work by Mosley, Hudson and

\footnotetext{
${ }^{*}$ The author is Professor of Economics, Lahore School of Economics.
} 
Horrel (1987) showed that while the conclusions regarding such putative relationships may be valid, there is nevertheless an interesting question regarding the effect of foreign assistance on intermediate policy variables such as public investment, government consumption and taxation. We pursue their lead and try to trace such a relation in a simultaneous equation model applied to an underdeveloped country, Pakistan. The results confirm the hypothesis that aid does affect consumption, investment and taxation in Pakistan. In particular, it is shown that grants and loans have different effects on investment and taxation. In the next section, we describe the model and derive the system of equations. The data, estimation procedure, and results are described in sections 3 and 4 respectively. Summary and conclusions follow.

\section{The Model}

Our aim is to develop a simultaneous equation model to estimate the effects of foreign aid on the taxation effort of the government and public current expenditure. We make the following assumptions regarding the actions of the public policy makers. They maximise their utility subject to:

a) alternative uses of public resources such as provisions for economic growth, spending for social and economic services, and for the maintenance of political institutions.

b) the distribution of total GDP between the private and the public sector.

c) alternative models of domestic financing, such as taxation and borrowing.

d) alternative types of external assistance, such as grants and loans.

Let us postulate the following general utility function for the policy makers at any time period:

$$
\mathrm{U}=\mathrm{f}(\mathrm{Ig}, \mathrm{T}, \mathrm{Gc}, \mathrm{Gs}, \mathrm{B}, \mathrm{A} 1, \mathrm{~A} 2)
$$

Where,

$\mathrm{Ig}=$ Public investment expenditure

$\mathrm{T}=$ Total tax revenue

$\mathrm{Gc}=$ "civil" consumption

$\mathrm{Gs}=$ Socioeconomic consumption

$\mathrm{B}=$ Borrowing from domestic sources 
A1 $=$ Total foreign grants to the public sector from all sources.

$\mathrm{A} 2=$ Total foreign loans to the public sector from all sources.

Ig is the public sector's contribution to the planned growth rate. It is measured by gross capital formation in the public sector plus net loans to the other sectors.

Gs, by definition, includes all current expenditures which are not intended for capital formation, but rather are spent for socioeconomic ends. This will include total government consumption. Therefore, Gs does include expenditure on health and education, i.e. some investment on human capital.

Gc, is the expenditure of the state to sustain itself. It includes administrative expenses, debt servicing, police security, defence forces and some transfer payments.

On the revenue side, tax policy is assumed to be a manipulable instrument. Hence the endogenous status of the tax variable. Borrowing is assumed to be a restriction yielding disutility to the policy makers.

External finance through $\mathrm{A} 1$ and $\mathrm{A} 2$ are viewed as exogenous to the model. These are controlled by aid giving agencies which are motivated by both political and economic factors.

Our model consists of three structural equations:

$$
\begin{aligned}
& I g=\alpha_{0}+\alpha_{1} I g^{*}+\alpha_{2} T+\alpha_{3} A_{1}+\alpha_{4} A_{2}+u_{1} \\
& G=\beta_{0}+\beta_{1} G+\beta_{2} T+\beta_{3} A_{1}+\beta_{4} A_{2}+\mathbf{u}_{2} \\
& G=\gamma_{0}+\gamma_{1} G^{*}+\gamma_{2} T^{*}++\gamma_{3} I g+\gamma_{4} A_{1}++\gamma_{5} A_{2}+\mathbf{u}_{3}
\end{aligned}
$$

There are 3 endogenous variables, Ig, T and $G$, where Ig is the development expenditure of the government, $G$ is the non-development expenditure which is the sum of Gc and Gs, and $T$ is the tax revenues of the government, and there are 5 exogenous variables. $A_{1} A_{2}, G^{*}, I g, T^{*}$.

The relationship yielding the target variables are as follows:

$$
\begin{aligned}
& \mathrm{Ig}^{*}=\alpha 11 \mathrm{Yt}-1+\alpha 12 \mathrm{Ip} \\
& \mathrm{T}^{*}=\alpha 13 \mathrm{Yt}-1+\alpha 14 \mathrm{Mt}-1 \\
& \mathrm{Gc}^{*}=\alpha 15 \mathrm{Gct}-1 \\
& \mathrm{Gs}^{*}=\alpha 16 \mathrm{E}+\alpha 17 \mathrm{Yt}-1+\alpha 18(\mathrm{Yt}-\mathrm{Yt}-1)
\end{aligned}
$$


Where,

$\mathrm{M}=$ Value of real imports

$\mathrm{E}=$ Primary school enrollment (in units of 10,000 students)

Ip $=$ Real private investment expenditure

Ig* can be expected to be influenced by the desired rate of growth of GDP/capita. Within a Harrod-Domar framework Yt-1 can be used as an instrument because $\mathrm{Ig}^{*}$ will be positively related to $\mathrm{Yt}-1$, given a target rate of growth. The relation between Ig and Ip may be complementary or substitutional. $\mathrm{E}$ is used as a proxy variable to measure the level of expenditure on Gs. Gc* increases at a constant proportion on a fiscal year basis. The planned level of taxes are determined by the previous year's income and the level of the previous period's imports.

\section{The Data}

We use time series data for the period 1980-2000 published by the World Bank. All aid data have been converted to real terms by dividing current values by deflators, the initial year price base is taken as 100 . All figures have also been converted to dollars by using the exchange rate for the appropriate years. The data for exogenous variables was calculated from estimating equations (4) to (7) using OLS and then using the parameter estimates to generate data for exogenous variables.

\section{The Empirical Results}

The Rank condition of identification showed that all the three structural equations are exactly identified. We have used 2SLS technique to estimate these three equations individually. The estimated equations describe the government's consumption, investment, and taxation behaviour in the presence of foreign aid. The estimates obtained for equations (1)- (3) are given in Table $1-3$ respectively.

Table-1: Dependent Variable: Development Expenditure

\begin{tabular}{ccc}
\hline Regressor & Parameter & t-statistic \\
\hline $\mathrm{Ig}{ }^{*}$ & 0.27 & 2.3 \\
$\mathrm{~T}$ & 0.074 & 25.6 \\
$\mathrm{~A} 1$ & 0.32 & 1.28 \\
$\mathrm{~A} 2$ & 0.85 & 1.2 \\
constant & -0.8 & -6.5 \\
\hline
\end{tabular}


Table 2: Dependent variable: Non-development expenditure

\begin{tabular}{ccc}
\hline Regressor & Parameter & t-ststistic \\
\hline $\mathrm{G}^{*}$ & 0.56 & 3.9 \\
$\mathrm{~T}$ & 0.08 & 22.3 \\
$\mathrm{~A} 1$ & 0.48 & 1.28 \\
$\mathrm{~A} 2$ & -0.21 & -1.1 \\
Constant & -3.2 & -6.5 \\
\hline
\end{tabular}

Table 3: Dependent variable: Tax revenues

\begin{tabular}{ccc}
\hline Regressor & Parameter & t-statistic \\
\hline $\mathrm{G}^{*}$ & 0.8 & 10.06 \\
$\mathrm{~T}^{*}$ & 0.52 & 12.34 \\
$\boldsymbol{h}$ & 0.192 & 3.8 \\
$\mathrm{~A} 1$ & -0.12 & 10.06 \\
$\mathrm{~A} 2$ & 1.21 & 3.9 \\
Constant & -3.2 & -4.0 \\
\hline
\end{tabular}

Table I shows estimation of equation (1) with investment as the dependent variable. The t-test shows that the parameter $\alpha_{3}$ and $\alpha_{4}$ are not statistically significant at the 0.05 level. Thus although grants and loans affect public investment positively, the variables are statistically not reliable. The results show that loans, however, have a larger effect on public investment than grants and that grants are wasted away on non-development projects. The parameters $\alpha_{1}$ and $\alpha_{2}$ are statistically significant. They also show a positive relationship between public investment and tax revenues and target investment. However, the contribution of taxes to public investment is weaker $(7.4 \%)$ while the growth rate of investment plays a larger role showing that the previous period's development projects cause an increase in to-day's public investment.

Table II shows estimation of equation (2) with non-development expenditure as the dependent variable. The t-test shows that the parameters $\beta_{3}$ and $\beta_{4}$ are statistically insignificant at the 0.05 level. Grants are positively related to non-development expenditure while loans are negatively related which shows that loans do encourage investment. The changes in nondevelopment expenditure also depend on the historical growth in public expenditure. The parameters $\beta_{1}$ and $\beta_{2}$ are statistically significant at the 0.05 level. The results show that changes in non-development expenditure are positively related to historical growth in public expenditure and tax revenues. The value of $\beta 1$ shows that $56 \%$ of public expenditure is on non-development activities. 
Table III shows the estimation of equation (3) with tax revenues as the dependent variable. The t-test shows that all the parameters are statistically significant at the 0.05 level. Interestingly, grants reduce the taxation effort, while loans increase it. The explanation for this is quite simple. Rational policy makers use nonrepayable grant money to reduce the tax burden, but the burden of loan repayment induces them to increase taxes. Previous tax efforts and public expenditures are also significant determinants of tax revenues. Tax revenues are also positively related to public investment expenditures that shows that an increase in tax revenues is also dependent on public investment.

\section{Summary and Conclusions}

A number of interesting conclusions and important policy implications can be arrived at from this study. Our results confirm the hypothesis that foreign aid affects both the expenditure and the revenue side of the Pakistan government's budget. On the non-development side, generally foreign aid is treated as an increase in income, and given positive income elasticity in the government sector there is an increase in nondevelopment expenditure. The parameters of A1 and A2 in Table 2 show that the marginal propensity to consume out of foreign aid is less than one. Therefore, some public investment is also financed from aid money.

There are important differences between aid in the form of grants and loans used for consumption as well as investment purposes by the government. Both loans and grants are used for consumption as well as investment purposes. But ceteris paribus, $85 \%$ of a dollar of loan received goes to investment as opposed to $32 \%$ of grants. Thus if the purpose of aid is to generate investment it is served much better by making loans to Pakistan's government than by giving grants.

Finally, aid also affects the tax efforts of the government. Interestingly, again grants reduce the tax burden as shown by the negative sign of the parameter of $\mathrm{Al}$ in Table 3 while loans increase it as shown by the positive sign of A2 in Table 3.

At the same time, the comparison of welfare effects of grants vs. loans may not be straight forward. Since grants do not have to be repaid, the reduction of taxes may seem to be more welfare enhancing than the effects of loans. Since loans, however, lead to relatively more investment and hence more income in the future, the net discounted benefits may very well be higher. This is an interesting area of future research. 


\section{References}

Aslam, Naheed, "The impact of foreign capital inflows on savings and investment: The case of 'Pakistan". Pakistan Development Review, Vol.26 (1987)

Central Statistical Office, Government of Pakistan, 25 Years of Pakistan in Statistics, 1947-7:2 Karachi: Government of Pakistan, 1972.

Chenery, H.B. and Adelman, I. "Foreign Aid and Economic Development: The case of Greece, Review of Economics and Statistics, Feb. 1966.

Chenery, H.B. and N. Bruno " Development Alternatives in an Open Economy: The Case of Israe1, Economic Journal Vol.77, No. 285, March, 1962, pp. 79-103.

Gang, I.N. and H.A. Khan "Foreign aid, taxes, and Public investment". Journal of Development Economics, Vo1.34 1991.

Griffin, K.B. and Enos, J.L. "Foreign Assistance: Objectives and Consequences", Economic Development and Cultural Change, Vol.18,1970, pp. 313-337.

Heller, P.S. "A model of Public fiscal behaviour in Developing countries: Aid, investment and taxation." American Economic Review, Vol.65,1975, pp. 429-445.

Heller, P.S., "Public Investment in LDC's with Recurrent Cost Constraint: the Kenyan Case", Quarterly Journal of Economics, Vol. 88,1974, pp. $251-277$.

Iqba1.Z. "Constraints of Economic Development of Pakistan: A three gap approach” Pakistan Development Review, 34: 1119-1133.

Khan, Haider Ali.and Hoshino, Ehchi." Impact of foreign aid on the fiscal behaviour of LDC Governments, World Development, Vo1.20, No.10, 1992 pp.1481-1488.

Khiiji, N.M. and Zampc1li, E.M. "The effect of US assistance on Public and Private expenditures in Pakistan”, Pakistan Development Review, 30:4 Part 2,1991, pp. 1169-1184. 
Mosley, P. Hudson, J. and Horre1, S., "Aid, the Public Sector and the Market in Less Developed Countries”, Economic Journal, Vol. 97, 1987 pp. 616-641.

Papanek, G.H., "Aid, Foreign Private Investment, Saving, and Growth in Less Developed Countrie", Journal of Political Economy, Vol.81,1973, pp. 120-130.

Please, S.,"Saving through Taxation- Mirage or Reality", Finance and Development, Vol.4,1967 pp.1-10.

Weisskopf, T., "The Impact of Foreign Capital Flow on domestic savings in Underdeveloped countries". Journal of International Economics, Vol.2,1972a, pp. 25-38.

Weisskopf, T. "An Econometric Test of Alternative Constraints on the Growth of Underdeveloped Countries", Review of Economics and Statistics, Vo1. 54,1972b,pp. 67-78. 